\title{
Determining Perception-Based Impacts of Noxious Facilities on Wage Rates and Property Values
}

Envirormental Assessment and Information Sciences Division Argonne National Laboratory

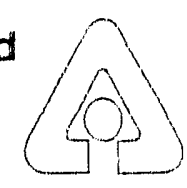

Operated by The University of Chicago, under Contract W-31-109-Eng-38, for the United States Department of Energy 


\section{Argonne National Laboratory}

Argonne National Laboratory, with facilities in the states of Illinois and Idaho, is owned by the United States govemment, and operated by the University of Chicago under the provisions of a zontract with the Department of Energy.

This technical memo is a product of Argonne's Environinental Assessment and Information Sciencess (EAIS) Division. For information on the division's scientific and engineering aclivities, contact:

Director, Environmental Assessment and Information Sciences Division

Argonne National Laboratory

Argonne, Illinois 60439-4815

Telephone (708) 252-3759

Presented in this technical memo are preliminary results of ongoing work or work that is more limited in scope and depth than that described in formal reports issued by the EAIS Division.

\section{Disclaimer}

This report was prepared as an account of work sponsored by an agency of the United States Govemment. Neither the United States Government nor any agency thereof, nor any of their employees, makes any warranty, express or implied, or assumes any legal liability or responsibility for the accuracy, completeness, or usefulness of any information, apparatus, product, ar process disclosed, or represents that its use would not infringe privately owned rights. Relerence herein to any specific comrnercial product, process, or service by trade name, trademark, manufacturer, or otherwise, does not necessarily constitute or imply its endorsement, recommendation, or favoring iby the United States Govemment or any agency thereot. The views and opinions of authors expressed herein do not necessarily state or reflect those of the United States Govemment or any agency thereof.

Avallable to DOE and DOE contractors from the Office of Scientific and Technical Information, P.O. Box 62, Oak Ridge. TN 37831; prices available from (615) 576-8401, FTS 626-8401. 


\section{Determining Perception-Based Impacts of Noxious Facilities on Wage Rates and Property Values}

by L.A. Nieves and D.E. Clark

Economics and Law Section

Environmental Assessment and Information Sciences Division

Argonne National Laboratory, 9700 South Cass Avenue, Argonne, Illinois 60439

July 1991 (printed February 1992)

Work sponsored by United States Department of Energy,

Office of Civilian Fladioactive Waste Management 


\section{CONTENTS}

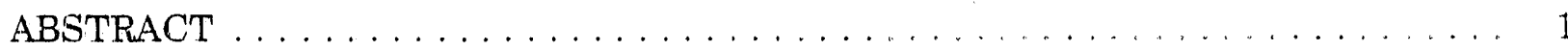

1 INTRODUCTION $\ldots \ldots \ldots \ldots \ldots \ldots \ldots \ldots \ldots \ldots \ldots \ldots \ldots$

2 DISCUSSION OF THE ISSUES $\ldots \ldots \ldots \ldots \ldots \ldots \ldots \ldots \ldots \ldots \ldots$

21 Effects of Local Characteristics on Wage and Property Markets . . . . . . . 3

2.2 Links between Risk Perception and Economic Impacts . . . . . . . . . . . . . . 4

2.2 .1 Impacts in Product Markets . . . . . . . . . . . . . . . . . . . 4

2.2.2 Impacts in Wage and Property Markets . . . . . . . . . . . . 5

3 METHODS AND INFORMATION BASE FOR MODEL IMPLEMENTATION $\ldots \ldots \quad 9$

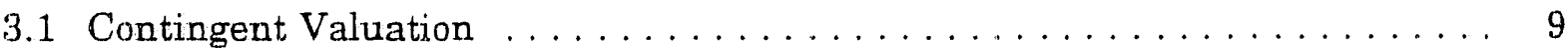

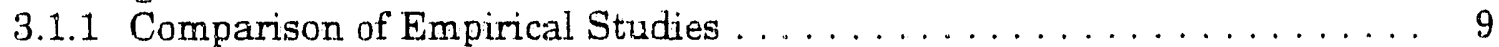

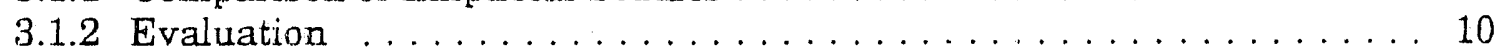

3.2 Hedonic Price Estimation . . . . . . . . . . . . . . . . . . . . 10

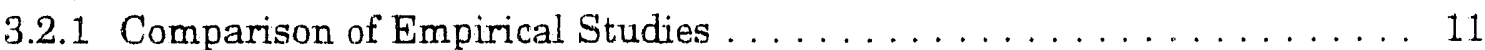

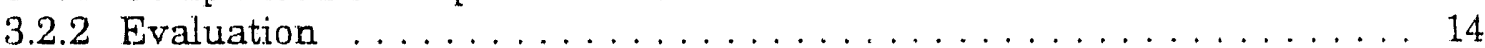

3.3 Psychometric Methods . . . . . . . . . . . . . . . . . . . . . . . 14

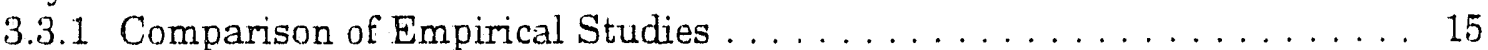

3.3 .2 Evaluation .............................. 15

4 A PREDICTIVE MODEL OF PERCEPTION-BASED IMPACTS $\ldots \ldots \ldots \ldots \ldots \ldots$

4.1 Key Variables . . . . . . . . . . . . . . . . . . . . . . . . 17

4.2 Locality and Facility Charasteristics . . . . . . . . . . . . . . . . 20

4.3 Net Market Impacts . . . . . . . . . . . . . . . . . . . . . . . . 20

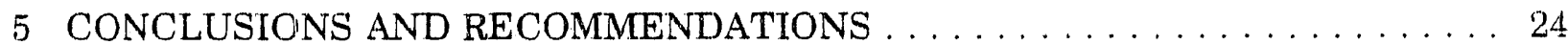

5.1 Model Implementation Feasibility . . . . . . . . . . . . . . . . . . . 24

5.2 Potential and Limitations of This Approach $\ldots \ldots \ldots \ldots \ldots \ldots \ldots$

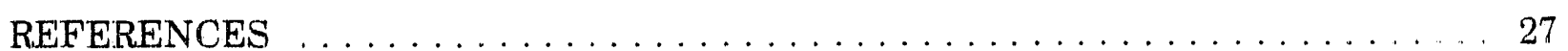

\section{FIGURES}

1 Linkage of Perceptions with Economic Impacts $\ldots \ldots \ldots \ldots \ldots$

2 Components of a Predictive Model for Net Impacts; Overall Structure . . . . . . 18

2a Components of a Predictive Model for Net Impacts; the Relationships of Locality Characteristics to Key Variables 


\section{FIGURES (Cont'd)}

$2 b$ Components of a Predictive Model for Net Impacts; the Relationships of Facility Characteristics to Key Variables.

\section{TABLES}

1 Hedonic Studies of Noxious Facility Impacts on Property Values . . . . . . . . 12

2 Hedonic Studies of Hazard-Related Impacts on Wages $\ldots \ldots \ldots \ldots \ldots \ldots \ldots$

3 Psychometric Studies of Noxious Facility Rankings $\ldots \ldots \ldots \ldots \ldots \ldots$ 


\title{
DETERMINING PERCEPTION-BASED IMPACTS OF NOXIOUS FACILITIES ON WAGE RATES AND PROPERTY VALUES
}

by

\author{
L.A. Nieves and D.E. Clark
}

\begin{abstract}
This document, written for the U.S. Department of Energy, discusses current irformation and the need for future research on estimating the impacts on wages and property values that could result from people's perceptions of the risks associated with noxious facilities. Psychometric studies indicate that the U.S. population is averse to living near noxious facilities, nuclear-related facilities in particular. Contingent valuation and hedonic studies find that the net economic impacts of proximity to noxious facilities are generally negative and often substantial. Most of these studies are limited in scope, and none estimate the impacts derived from public perceptions of such facilities. This study examines the mechanisms by which negative public perceptions result in economic impacts reflected in wages and property values. On the basis of these mechanisms, it develops a predictive model of perception-based impacts and identifies the data and methods needed to implement it. The key to predicting perception-based impacts lies in combining psychometric and hedonic methods. The reliability of psychometric measures as indicators of aversive stimuli that precipitate economic impact.s can be empirically tested. To test the robustness of the findings, al cernative estimation methods can be employed in the hedonic analysis. Contingent valuation methods cari confirm the results.
\end{abstract}

\section{INTRODUCTION}

This report provides guidance to the U.S. Department of Energy on the state of knowledge regarding perception-based impacts on wage and property values; it describes a framework and techniques by which dollar estimates of such impacts can be calculated. Existing studies that provide an information base for model development are reviewed, and gaps and discrepancies in the literature are discussed. A conceptual model of the relationships among factors involved in perception-based impacts is presented to clarify the mechanisms by which wages and property values are affected. The framework for a predictive model is developed, and the availability of the information and methods needed to implement the model are evaluated. 
Section 2 describes the major issues involved in measuring the economic impacts due to changes in perceived risks in a given locale. After covering the effects of local characteristics on wage and property markets, it examines the process by which changes in perceived risks create impacts. Section 3 discusses the methods and information available, in the form of empirical studies and databases, that can be used to implement a predictive model. Section 4 develops the framework for a predictive model of im pacts of facility-related perceived risks. This discussion is followed by conclusions and recommendations for a research agenda in Section 5. 


\section{DISCUSSION OF THE ISSUES}

Impacts may be generated by both the construction and operation of a noxious facility ${ }^{*}$ and by changes in people's behavior as a result of their perceptions of the facility. Although there are many types of impacts that can affect individuals, impacts on wages and the property market provide a type of "bottom line" measure in dollar terms. Recent research has shown that a property's value is jointly determined, oy the specific features of the property and by the characteristics of its location. Wage rates are also jointly determined, by skill requirements and by aspects of the location. The ways in which an area's characteristics are reflected in these markets are discussed below. Since perception-based impacts are the major concern of this report, the effects of risk perception on behavior and, in turn, on these markets are examined in detail.

\subsection{EFFECTS OF LOCAL CHARACTERISTICS ON WAGE AND PROPERTY MARKETS}

Since the 1970 s, it has been recognized that regional variation in amenities and disamenities can affect housing prices and market wages by influencing the location choices of households and workers. Specifically, workers pay for better amenities in a region by accepting lower real market wages to live in those areas. Conversely, economic compensation is required by the worker, in the form of a wage premium, to endure a relatively poor amenity mix. These wage differentials result from the movement of workers in and out of a region in response to the amenity mix. In the housing market, that same movement of workers generates housing price differences. Residents pay for relatively attractive amenities in the form of higher housing prices, while housing prices fall in response to disamenities. Wage and housing price differentials are important forms of market compensation, dampening the motivation to move to more amenable locations. Without such differentials, more amenable locations (those with relatively attractive amenities) would offer levels of satisfaction higher than those of less amenable locations, resulting in continual migration of population from low-satisfaction to high-satisfaction locations.

These wage and housing market variations represent market signals to policymakers attempting to evaluate the economic impact of a particular type of facility. Wage and housing price differentials reveal the actual value that households or workers place on the amenity or disamenity attributes of the facility. Thus, any attempt to estimate appropriate compensation for the siting of a facility that generates a disamenity (such as health risks) must consider estimates of wage and property value impacts.

\footnotetext{
"We assume in this report that risk mitigation would be undertaken first, that is, by constructing a facility that is state of the art and by taking all reasonable physical and institutional measures to mitigate risks. To the extent that a facility is not perceived as state of the art, impacts would be magnified.
} 
The impacts on market wages and housing prices are not independent of one another. For example, in a region with a higher level of perceived risk as the result of a facility being sited there, most of the impact could be reflected in lower housing prices. Alternatively, the majority of the influence could be retlected in higher market wages, with only a relatively minor influence on housing prices in evidence. The distribution of impacts between wages and housing prices depends on numerous factors, such as the fraction of the resident population that is retired and the degree to which the disamenity differentially impacts the work site versus the place of residence, family structure, etc. However, the total compensation estimates are derived from the trital impact on both housing prices and market wages rather than from their separate impacis.

\subsection{LINKS BETWEEN RISK PERCEPTION AND ECONOMIC IMPACTS}

Links between product characteristics (e.g., image and expected durability) and the market behavior of consumers have long been a subject of study. For example, Taylor (1974) presents a theory of the effect of perceived risk on consumer behavior and reviews marketing studies that address risk perception. However, the scope of such studies has rarely focused on estimating the dollar value of perception-based impacts on markets. Some of the typical behaviors that people employ to deal with uncertainty and perceived risks are brietly described below. This description is followed by a more detailed discussion of the relationships between perceptions, behaviors employed to adapt to changes in risk perceptions, and impacts reflected in wage and property markets.

\subsubsection{Impacts in Product Markets}

One of the concerns of consumer economics and marketing studies has been the process by which people select among substitutable products on the basis of product image, price, relative certainty about quality, and other product characteristics. Information and resulting perceptions about health risks are factors that affect product demand. Numerous cases have been documented of product markets in which information about a purported health risk led to a precipitous short-term decline in sales, followed by a gradual recovery to normal or near-normal levels. This situation has occurred recently in repeated incidents of tampering with pharmaceutical products and identification of safety-related defects in automobile;. Often consumer avoidance of the product has persisted in the short term ex... though all contaminated products have been removed from the market or official investigation has found no evidence of the suspected contamination or health risk. Swartz and Strand (1981) document the relationship between intensity of news coverage and consumer avoidance of uncontaminated oysters following reports of kepone contamination of the James River in Virginia. They developed dollar estimates of the market impacts. specifically relating those im pacts to the flow of news about oyster contamination at the other end of the Chesapeake Bay.

Consumer efforts to avoid a perceived risk may also affect product markets not directly implicated in the risk. For instance, there have been several cases of contamination 
of a single seafood product in which the release of information about the risk has iffected sales of same seatood products, but from other locations and sales of other seafood products. Examples include botulism from tuna (Doherty 1964), botulism from Great Lakes whitefish (Doherty 1964), rnercury in tuna (Griswold 1972), and aminotriazole in cranberries (Doherty 1964).

\subsubsection{Impacts in Wage and Property Markets}

The market impacts described above pertained to goods in markets not delined by geographical boundaries. Housing and wage markets differ from these to the extent that their characteristics are associated with specific locations, since commuting costs limit the distance a worker is willing to travel between residence and workplace. To select different combinations of environmental characteristics, people must move between fixed market locations. Changes in perceptions of a locality may alter people's preferences for living and working there rather than elsewhere, thus generating migration flows. Knapp and Graves (1989) thoroughly reviewed the theory, methods, and findings of studies of the determinants of interregional migration. They found that local amenities play an important role in influencing migration. Recent studies of effects of amenities have moved toward integrating hedonic models with migration models.

A model of the process by which changes in perceptions of local characteristics I due to siting of a noxious facility) affect local wages and property values is presented in Figure 1. Major stages in the process are listed across the top of the figure, beginning with the stimulus that alters the status quo and ending with the net economic impact. The context of these adjustments is indicated across the bottom. We assume that the local economy is initially in equilibrium: property values and wage rates are stable, and the in- and outmigration flows are balanced, with a net flow of zero.

The process begins with the facility siting decision affecting a specific location with a particular set of social, economic, and environmental characteristics. Information about the decision is transmitted to the public by various sources, likely to represent a range oi opinions. This information flow takes place within a social and political context that influences local perceptions about the facility and local expectations regarding its effects. At this stage, risk amplification effects, such as Kasperson et al. (1988) describe, commonly occur because people do not know what to realistically expect.

The prospect of a noxious facility nearby is likely to generate expectations regarding three major categories of effects. First, on the positive side, is the possible increase in employment opportunities directly or indirectly related to the facility's operation. These new jobs could be at the facility itself or in local firms as a result of the stimulation of the local economy through the income of the facility's employees and through the direct purchases of goods and services for facility operation. The relative value of these opportunities to local residents will depend in large part on existing economic conditions in the area. Areas with a large proportion of currently unemployed or underemployed local residents are likely to value such opportunities highly. 


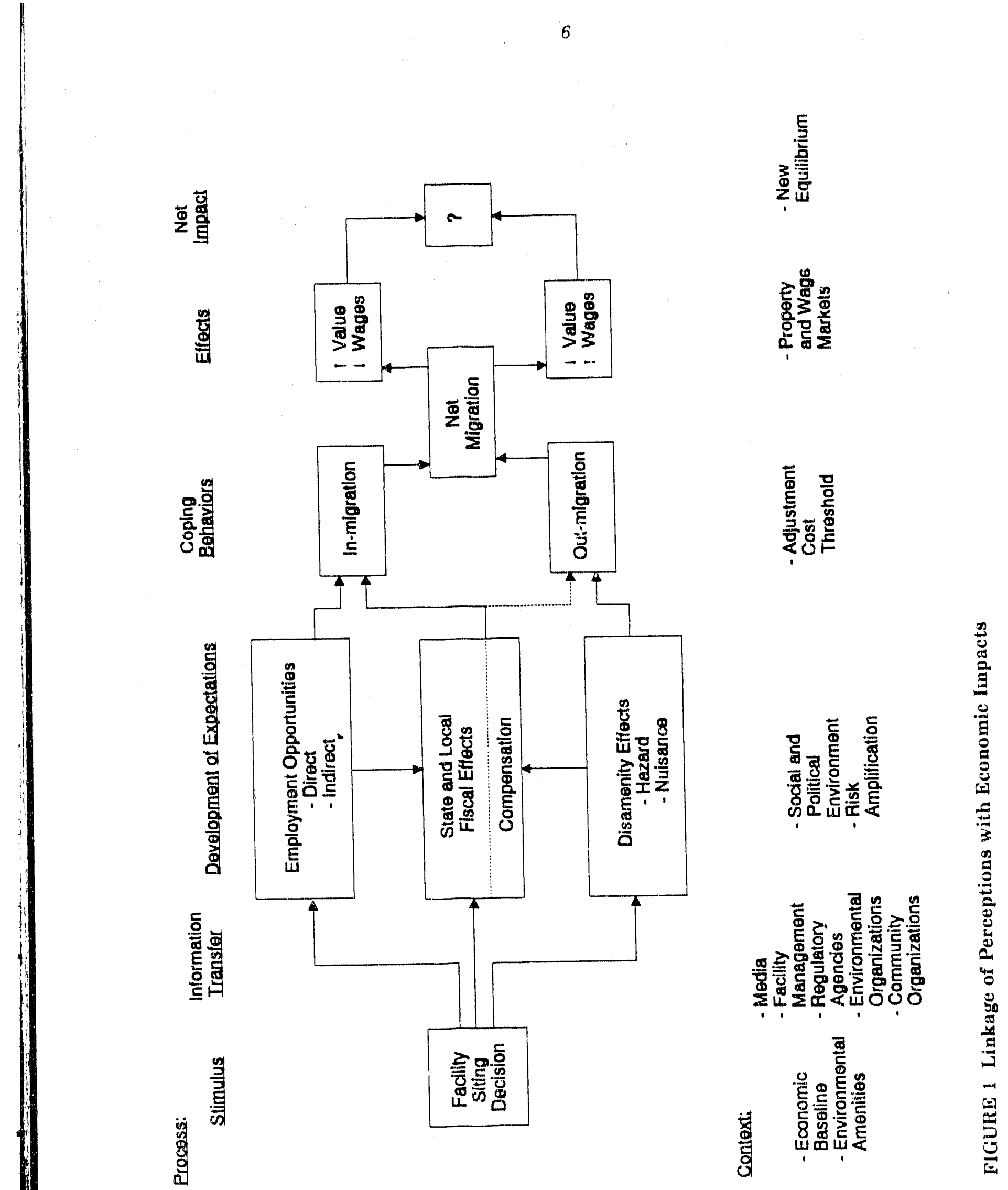


Second, on the negative side, the public may develop expectations about the disamenity effects of the facility. Potentially hazardous aspects of the facility will result in perceived risks of damage to persons and the environment. Also creating expectations of negative impacts are nuisance aspects of the facility, including characteristics such as noise, traffic, dirt, and so forth.

Third, negative expectations regarding hazard and nuisance effects of a facility may both lead to and interact with expectations of compensation. Although such compensation may be provided in various forms such as taxes paid by the facility or payments in lieu of taxes, it is generally provided to local governments rather than to individuals, when there is no damage to specific individuals. Besides being affected by comperisation, state and local governments experience fiscal effects from the expansion of employment generated by the facility. Property tax receipts generated by the facility can be used either to offer greater government services for local residents or reduce the residential tax burden. Better services relative to the tax burden enhance property values and reduce the wages required to induce people to live in an area, given equivalent amenities. However, as people move into an area, the demand for government services increases, making the net fiscal effect uncertain.

Changing the balance of an area's characteristics induces behaviors to cope with the change and to restore equilibrium. These actions generate perception-based economic impacts. Positive expectations of a facility's effects provide an impetus for net in-migration to the area, while negative expectations promote a net out-migration of population." Migration is more likely to be triggered by major changes than by minor ones, since there are generally substantial transaction costs involved in moving. If the value that people place on the expected effects is below some adjustment cost threshold, people will feel that they are less well off but will not move. They may, however, be motivated to invest in protest activity up to the point where the personal costs of such activity are equal to the cost of moving. The level of this adjustment-cost threshold car vary greatly among individuals, depending on their ties to a given locality.

Since there is always some in-migration to and out-migration from an area, the critical factor in creating impacts is whether net migration is positive or negative. Net migration affects the demand for housing and the supply of labor, in turn affecting wage rates and property values. If the net migration flow increases an area's population, housing prices will tend to rise and wages to fall; the opposite effect will occur if net migration is negative. The summation of the changes in property values and wage rates represents the net impacts required to reach a new equilibrium (Schachter and Althaus 1989; Mathur and Stein 1991).

At any point in the adjustment process, local wages and property values reflect the most current information and expectations regarding probable risk and probable compensation. During the initial phases of the siting process, substantial uncertainty with

\footnotetext{
"See Kiecolt and Nigg (1982) for an investigation of earthquake risk perception and other factors related to intention to move out of the Los Angeles area.
} 
respect to both risk and compensation exists. This uncertainty is likely to generate short-run impacts that will change over time and differ from the eventual long-run impacts.

The model discussed above provides a basis for developing a predictive model of property value and wage impacts. The next section describes methods that can be applied to model development and studies that have addressed a portion of the required scope of a predictive model. That discussion is followed by presentation of the predictive model framework and key variables as well as data to implement it. 


\section{METHODS AND INFORMLATION BASE FOR MODEL RMPLEMENTATION}

Analytical methods to support the development of a predictive model are available in the fields of economics and social psychology. This section provides an overview of these methods, a description of relevant studies in which they have been employed, and a discussion of how they can be applied to the problem of predicting noxious facility impacts.

\subsection{CONTINGENT VALUATION}

Contingent valuation is the general term applied to surveys that ask people to place monetary values on goods or environmental changes for which no market exists. They usually involve interviewer-administered questions about the amount that a household would be willing to pay for an improvement in environ zental quality or would be willing to accept for a decrease in quality. Questions can also be framed in terms of likely changes in household behaviors, such as a person's likelihood of visiting a location or of choosing housing located at alternative distances from a noxious facility.

As Randall et al. (1983) note in their review of contingent valuation methods, because the respondent is asked to evaluate a hypothetical situation, precise specifications are required for the environmental change, for the organizational framework controlling it, and for the mechanisms for any monetary transfers. Brookshire and Crocker (1981) indicate that the degree to which the impact estimates developed by contingent valuation methods correspond to actual impact depends on the accuracy and imaginableness of the information provided to survey respondents. Although it is a cause for caution in applying this method, the hypothetical nature of contingent market valuation is also the main reason for its value, in that it provides a method of ex ante ${ }^{*}$ evaluation of environmental changes.

\subsubsection{Comparison of Empirical Studies}

The type of information that can be obtained by a contingent valuation survey is exemplified by Bajgier and Moskowitz's (1978) study of the relative importance of perceived risks in a person's willingness to pay for removing contaminants from drinking water. They examined the role of water characteristics such as hardness in determining perceptions of water quality and beliefs about contamination of respondents' drinking water and that of others. The effect of providing information about drinking water quality and about relative risks to life and health was also investigated. They tound that people are willing to pay more to avert identical statistical risks if the cause of the risks is specified and that they are

\footnotetext{
"Ex ante ("from before"): the forward-looking view. Ex ante refers to future economic activity.

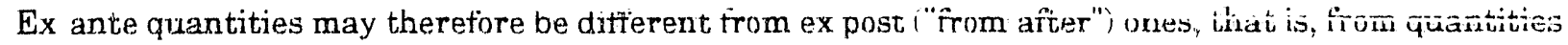
describing past economic activity.
} 
willing to pay the most to avoid risks from radioactive contaminants (even more than for a carcinogen).

Contingent valuation studies of various environmental resources and changes in their quantity or quality have been published. Only one study has been identified that applies such methods to valuation of a noxious facility site. Smith and Desvousges $(1986,1987)$ used a contingent market survey to obtain bids for the changes in risk associated with a hypothetical hazardous waste landfill. The findings were inconsistent with those of many contingent valuation studies in that the respondents were willing to pay more to reduce risk by a given amount than they were to avoid an equal increase in risk level. The authors attributed this finding to a property rights effect - a belief on the part of the respondents that they are entitled to the status quo and should not have to pay to limit risk.

\subsubsection{Evaluation}

Despite numerous empirical applications of contingent valuation methods, many questions remain about the effect of the survey design on the results. Several types of potential bias have been identified. The type with the most implications is probably strategic bias. This occurs when people indicate bids that do not truly reflect their personal willingness to pay for an environmental change but that seek to influence the outcome of the study. This type of response is most likely when the respondent, expecting to be personally affected by a particular environmental change, feels strongly about the outcome. Several studies have examined the potential for stratejic bias. Brookshire and Crocker (1981) and Randall et al. ( 1983 ) conclude that there was no clear evidence of it in practice. Seller et al. (1985) suspected its presence, while Cronin (1982), explicitly testing for strategic and other forms of bias, found significant evidence of it.

Ever with the difficulties in implementation, the contingent valuation survey is rapidly gaining acceptance as a valuation tool because of its ability to produce estimates corresponding to total impacts as defined by economic theory. The contingent valuation method is designed to estimate the total amount people are willing to pay for an environmental change. Such a survey could be carried out to estimate the property value and wage differentia's that would equate in- and out-migration following siting of a noxious facility in an area. Using those estimates to determine the compensation necessary to reach such a market equilibrium with the facility in the area would require econometric modeling of the relationship between compensation and wages and property values while controlling for employment and disamenity effects as represented in Figure 1.

\section{:3.2 HEDONIC PRICE ESTIMATION}

Hedonic models use market data to measure the value of environmental goods lor bads) that are not themselves traded in markets. By analyzing prices in a related market, these models provide a means of discovering the implicit value that people ascribe to the environmental characteristic. Most applications of hedonic methods have focused on markets 
for single-family residences, although there have been a few studies involving rental housing markets. A number of hedonic studies have also analyzed the relationship between environmental amenities or disamenities and wage rates.

The hedonic approach assumes that consumers perceive goods as bundles of features and that goods with all possible combinations of the features are available in the market. for housing, the relevant features are attributes such as age of the structure; number of roums; lot size; presence of a garage; presence of fireplaces; neighborhood characteristics; access to transportation, shopping, and schools; and environmental conditions such as crime rate, climate, and access to recreational opportunities. The implicit value of each of these attributes can be measured by regressing attribute data (for houses representing the full range of characteristics) on the price. This implicit attribute price is interpreted as a representative household's willingness to pay for an additional unit of that attribute. Hedonic models have been commonly used to value attributes such as air pollutant concentration levels, location in floodplains or earthquake risk zones, and proximity to noxious facilities.

Hedonic methods produce relatively consistent results across locations (Freeman 1979 ) in spite of the potential pitfalls in their implementation. Studies have generally tound that areawide environmental conditions have statistically signiticant eftects on price levels in the market analyzed. Roback's work (1982), which evaluated a variety of amenities and disamenities, is especially important because it examined the relationship between property and labor markets and showed that environmental attributes affect prices in both simultaneously. Disamenities such as noxious facilities can lower property values or raise wages, or both.

Because they have overiooked the interrelationships of property and wage markets when analyzing the implicit prices of perceived risks or nuisances, many studies have produced biased implicit price estimates for disamenities. Methods have been developed to estimate unbiased implicit prices for amenities; these use either property data or labor market data while controlling (in the hedonic regression equation) price levels in the other market not being used. This technique can estimate noxious facility impacts by using detailed data for only one market, but it may be even more valuable as a means of confirming impact estimates by developing values separately for each market.

\subsubsection{Comparison of Empirical Studies}

Tables 1 and 2 provide an overview of the hedonic literature treating hazards and noxious facilities. The tirst table summarizes the types of facilities included in each study and the relevant findings about property value impacts. The second presents similar information for wage impacts.

Most property value studies that evaluate the effects of noxious facilities deal with one or several individual communities. These studies typically tocus on identifying property 
TABLE 1 Hedonic Studies of Noxious Facility Impacts on Property Values

Noxious Facilities

Landfill

Landfill

Landfill, industrial sites,

hazardous waste sites

Hazardous waste sites

Supertiund sites, waste treatment sites

Public housing, industry, commercial development

Manufacturing

Coal-tired electric plant

Chemical manufacturing

Nuclear plantis

Three Mile Island (TMI) nuclear facility

Nuclear materials production

Liquified natural gas (LNG) storage; chemical weapons. storage; coal, gas and oil, and nuclear plantis; retineries; Formerly Utilized Sites Remedial Action Program (FUSRAP) sites; hazardous waste sites
Presence of perceptual signals (e.g., odor) tied to health risk belief's is associated with lower values.

Prices are lower near garbage truck route, treeway, and gravel pit. Values are unaffected by distance from landfill with in the study radius.

Proximity to industrial sites increases prices. Proximity to hazardous waste lowers them.

Proximity to sites lowers values.

Net impacts on wages and housing values are negative.

Industry and public housing lower prices. No effects result from commercial development.

Industry increases values, but air-polluting industries lower them.

Proximity to plant lowers prices.

Proximity to chemical plantis and higher levels ot air pollution lower pricess. No change occurred as a result of the Bhopal accident.

No significant effect on valuess was found.

No price change resulted from the TMI accident.

Sales prices increase after announcement of discharge. Distance effect is unclear.

Chemical weapons storage; coal, gas and oil, and nuclear plants; and refineries decrease home values. Hazardous waste and L,NCr storage sites are associated with higher values.
Meclelland, Schulze, and Hurd 1990

Schmalenset et al. 1.975

Harrison and Stock 1984

Michaels and

Smith 1990

Hoehn, Berger, and Blomquist 1987

Grether and Mieszkowski 1980

Burnell 1985

Blomquist 1974

Baker 1986

Gamble and Dowring 1981

Nelson 1981

$R=a l$ Estate Counseling Group and Financial Consulting Group 1987,1989

Nieves, Hemphill, and Clark 1991 
TABLE 2 Hedonic Studies of Hazard-Related Impacts on Wages

\begin{tabular}{|c|c|c|}
\hline Hazard Type & Findings & Author \\
\hline Deaths & $\begin{array}{l}\text { Positive wage differentials for increased } \\
\text { risk. }\end{array}$ & Brown 1980 \\
\hline Fatality rate & $\begin{array}{l}\text { Positive wage differentials for increased } \\
\text { risis. }\end{array}$ & $\begin{array}{l}\text { Herzog and } \\
\text { Schlottmann } 1990\end{array}$ \\
\hline Risk of death & $\begin{array}{l}\text { Married and union workers obtain higher } \\
\text { wage differentials for risk. }\end{array}$ & $\begin{array}{l}\text { Thaler and Rosen } \\
1976\end{array}$ \\
\hline Risk of injury & $\begin{array}{l}\text { Union workers receive higher wage } \\
\text { differentials for risk. }\end{array}$ & $\begin{array}{l}\text { Biddle and Zarkin } \\
1988\end{array}$ \\
\hline $\begin{array}{l}\text { Superfund sites, waste } \\
\text { treatment sites }\end{array}$ & $\begin{array}{l}\text { Net impacts on wages and housing values } \\
\text { are negative. }\end{array}$ & $\begin{array}{l}\text { Hoehn, Berger, and } \\
\text { Blomquist } 1957\end{array}$ \\
\hline $\begin{array}{l}\text { ENG storage; chemical } \\
\text { weapons storage; coal, gas } \\
\text { and oil, and nuclear } \\
\text { plants; refineries; } \\
\text { FUSRAP sites; Superfund } \\
\text { sites }\end{array}$ & $\begin{array}{l}\text { LNG storage and refineries increase area } \\
\text { wage rates. }\end{array}$ & $\begin{array}{l}\text { Nieves, Hemphill, } \\
\text { and Clark } 1991\end{array}$ \\
\hline
\end{tabular}

value gradients related to distance from the study facility. Although highly consistent in finding facility proximity to be associated with depressed property values, these studies do not provide a good basis for generalizing to other sites or projecting impacts for sites on which there is not yet a facility. Because the basis of analysis is a single community, these studies do not incorporate data for characteristics that affect property values but vary across communities, such as population density, climate, and other amenities and disamenities.

Only two studies listed use an interregional modeling approach that controls for differences in basic community environment when measuring the effects of noxious facilities. (This approach has been employed, however, in numerous studies of price effets of crime rates, climatic characteristics, etc.) Hoehn, Berger, and Blomquist (1987) calculated, tor wage and property markets combined, a net impact from Superfund sites and hazar hous waste treatment, storage, and disposal sites. This net impact takes the simultaneous im teraction of wage and property markets into account; results show that both types of antes have depressing effects on the local markets." The second study, by Nieves, Hemphill, and Clark (1991) tound that property values decrease as the density of each facility type increases, except for hazardous waste and LNG storage sites.

\footnotetext{
"Baker (1986) also calculated net impacts but did so by controlling for income in the analysis of chemical plant effects on property values.
} 
More limited in number, the hedonic studies of wage rates all follow the same basic approach but use large, cross-sectional samples. As shown in Table 2, most address the effects of job injury or fatality risks. Noxious facility effects on local wage rates were investigated only in the studies by Hoehn, Berger, and Blomquist (1987) and Nieves, Hemphill, and Clark (1991). The latter study found that an incriasing density in most facility types is associated with increased wage rates, but only those finclings tor refineries and $\mathrm{LNG}$ storage sites are statistically significant.

\subsubsection{Evaluation}

Hedonic estimation techniques underwent substantial development during the 1980s, with the result that many earlier studies can now be faulted on methodological grounds. In addition, the findings of many property value studies may have been affected by the small size of the region selected. Most of these studies found that price gradients decrease with increasing distance from a noxious facility, but they lacked a basis for determining whether the price level in the whole area differed from that in comparable areas. The wage studies, in contrast, were based on national samples. They did not generally deal with employment in or near noxious facilities, however. At this point, the only available analysis of both wage and property impacts for a variety of noxious facilities is by Nieves, Hemphill, and Clark (1991).

In spite of the methodological tlaws and limited scope of the texisting research, the findings are consistent. The wage analy ses clearly document positive wage differentials tior exposure to risks. The property studies generally indicate that property values decrease as proximity to noxious facilities increases. It appears, however, that the impacts of industrial facilities (and perhaps other facility types) may be either positive or negative, depending on their effect on air quality, among other factors. Baker (1986) and Nelson (1981) found no price impacts from the effects of an accident, which indicates that public expectations of such accidents were already fully capitalized in property prices. Furthermore, in two studies that. found insigniticant or positive price impacts, there are indications that compensation or expectations of it) may have been responsible (Gamble and Downing 1981; Real Estate Counseling Group and Financial Consulting Group 1987). Thus, the findings of hedonic price and wage analyses are generally consistent with the model of perception-based impacts shown in Figure 1, although none has had comparable scope or detail. The studies that permit assessment of net impacts on labor and property markets (Baker 1986; Hoehn, Berger, and Blomquist 1987; Nieves, Hemphill, and Clark 1991) indicated a negative effect: from noxious facilities.

\subsection{PSYCHOMETRIC METHODS}

The tield of psychology has produced many techniques for measuring attitudes, including survey and experimental approaches. Some of these have been developed specifically to provide data on information processing and decision making under uncertainty isee Kahneman, Slovic, and Tversky 1982! for an overview of the literature on underlying 
cognitive processes). Such psychometric studies generally have a structure that elicits respondents' perceptions or reveals their thought processes by requiring them to rank alternatives or choose among al ternative outcomes.

Psychometric methods have been applied to areas such as consumer decision making, adaptation to natural hazard risks, and aversion to noxious facilities. Crolant and Burton (1969) illustrate the potential scope of this method and the general approach applied in more recent studies. They asked respondents to rank selected natural, physical, and social hazards by the degree to which they desired to avoid them. The relative rankings of hazards by persons who had and had not experienced them were compared. Relationships between these rankings and respondents' socioeconomic and personality characteristics were then analyzed.

\subsubsection{Comparison of Empirical Studies}

Table 3 lists a limited number of psychometric studies focusing on aversion to noxious facilities and perceived risks of technological hazards. In these surveys, conducted between the mid-1970s and the late 1980s, nuclear plants and nuclear wastes consistently received the highest ranking in regard to perceived risks. This ranking transcented geographical boundaries: the tirst three studies were conducted in the United States, while the last was conducted in Europe. Some variation in risk evaluations was shown within the groups surveyed, however. Lindell and Earle (1983), for instance, found that nuclear engineers as a group are most willing to live near a nuclear plant, while environmentalists are least willing to do so. Maderthaner et al. (1976) found that those presently living close to a nuclear plant rated it as less risky than did those living tarther away. Whether these differences are due to tamiliarity with the technology or selt-selection into the groups studied, they indicate the potential of psychometric techniques to identify differences in risk perceptions among population subgroups.

\subsubsection{Evaluation}

Psychometric techniques are an extension of basic survey methods of scale development. As such, the methodology is relatively well developed and has been applied in a wide variety of contexts. Application of the method to risk evaluacion has been demonstrated in several studies, with consistent results. While some previous studies of perceived risks include a range of facility types relevant for assessing perceptions of relative risks of a nuclear waste repository, none of these involved a national sample that would permit interregional analysis. To the extent that impacts are the result of risk perceptions, psychometric methods of identifying perceptions of the relative risk of facilities provide a crucial link in the information needed to project impacts of new facilities. 
TABLE 3 Psychometric Studies of Noxious Facility Rankings

\begin{tabular}{|c|c|c|}
\hline Hazards & Findings & Author \\
\hline $\begin{array}{l}\text { Gas, oil, coal, and nuclear plants; LNG } \\
\text { storage; refineries; hazardous waste, } \\
\text { nuclear waste }\end{array}$ & $\begin{array}{l}\text { Aversion ranking: gas } \\
\text { lowest, nuclear waste highest }\end{array}$ & $\begin{array}{l}\text { Lindell and Earle } \\
1983\end{array}$ \\
\hline $\begin{array}{l}\text { Landfill, chemical landfill, coal and } \\
\text { nuclear plants, refinery, pesticide } \\
\text { manufacturing, nuclear waste }\end{array}$ & $\begin{array}{l}\text { Aversion ranking: landfill } \\
\text { lowest, nuclear waste highest }\end{array}$ & $\begin{array}{l}\text { Mountain West } \\
1989\end{array}$ \\
\hline $\begin{array}{l}\text { Home and job accidents, nuclear } \\
\text { plants, hazardous chemicals, nuclear } \\
\text { waste, nuclear weapons testing }\end{array}$ & $\begin{array}{l}\text { Serious ness of risk scale: } \\
\text { home accident lowest, } \\
\text { nuc. raste highest }\end{array}$ & $\begin{array}{l}\text { Kunreuther, } \\
\text { Desvousges, and } \\
\text { Slovic } 1988\end{array}$ \\
\hline $\begin{array}{l}\text { Gas works, district heating facility, oil } \\
\text { refinery, mental hospital, nuclear } \\
\text { reactor, prison, airport }\end{array}$ & $\begin{array}{l}\text { Rist } \quad \text { ing: nuclear plant } \\
\text { high w axcept for people } \\
\text { living within } 500 \text { meters }\end{array}$ & $\begin{array}{l}\text { Maderthaner, } \\
\text { Pahner, Guttmann, } \\
\text { and Otway } 1976\end{array}$ \\
\hline
\end{tabular}




\section{A PREDICTIVE MODEL OF PERCEPTION-BASED IMPACTS}

Up to the present, no predictive models of perception-based impacts have been developed, and no estimates isolating such impacts from other effects exist. Methods that can be linked to construct a predictive model have been developed and tested, however. This section presents information on a framework, key variables, methods, and data that can be used to estimate a predictive model for perception-based impacts on wages and property values.

The most basic requirements for a predictive model of unique noxious facility impacts $^{*}$ are information on (1) historical relationships between the characteristics of host areas and the property and wage market impacts associated with various noxious facilities and $(2)$ the public's aversion to the unique type of noxious facility relative to other facilities for which historical data are available. Using the information on the mechanisms by which impacts are generated, one can project impacts of unique noxious facilities by relating their characteristics (and the intensity of public aversion to them) to the characteristics of facilities whose economic impacts are known. Figure 2 is a diagram of the overall structure of such a predictive model tor economic impacts on property values and wages.

\subsection{KEY VARLABLES}

The key variables in the predictive model are the effects, or changes from the status quo, which provide an impetus for coping behavior. Three of these variables are likely to create incentives tor in-migration.

The must important of these variables is the magnitude of facility employment relative to the employment base in the host area. New employment opportunities may have a nonlinear stimulating effect on migration depending on whether the new employment is $500 \%, 50 \%$, or $0.5 \%$ of the base level. The absolute size of base employment and the capacity of the existing economic infrastructure for expansion of services may also contribute tr differential effects.

The second key variable is the indirect employment multiplier effect that the 'acility may have in promoting growth of the host area's economy. This effect depends on the magnitude of the employment change and the amount of goods and services purchased locally. The employment response of the local labor market is also determined tiy its absolute size, industrial structure, and other factors related to expansion capacity.

\footnotetext{
"This model is designed for application to the siting of either a permanent geological repository or a monitored retrievable storage site.
} 


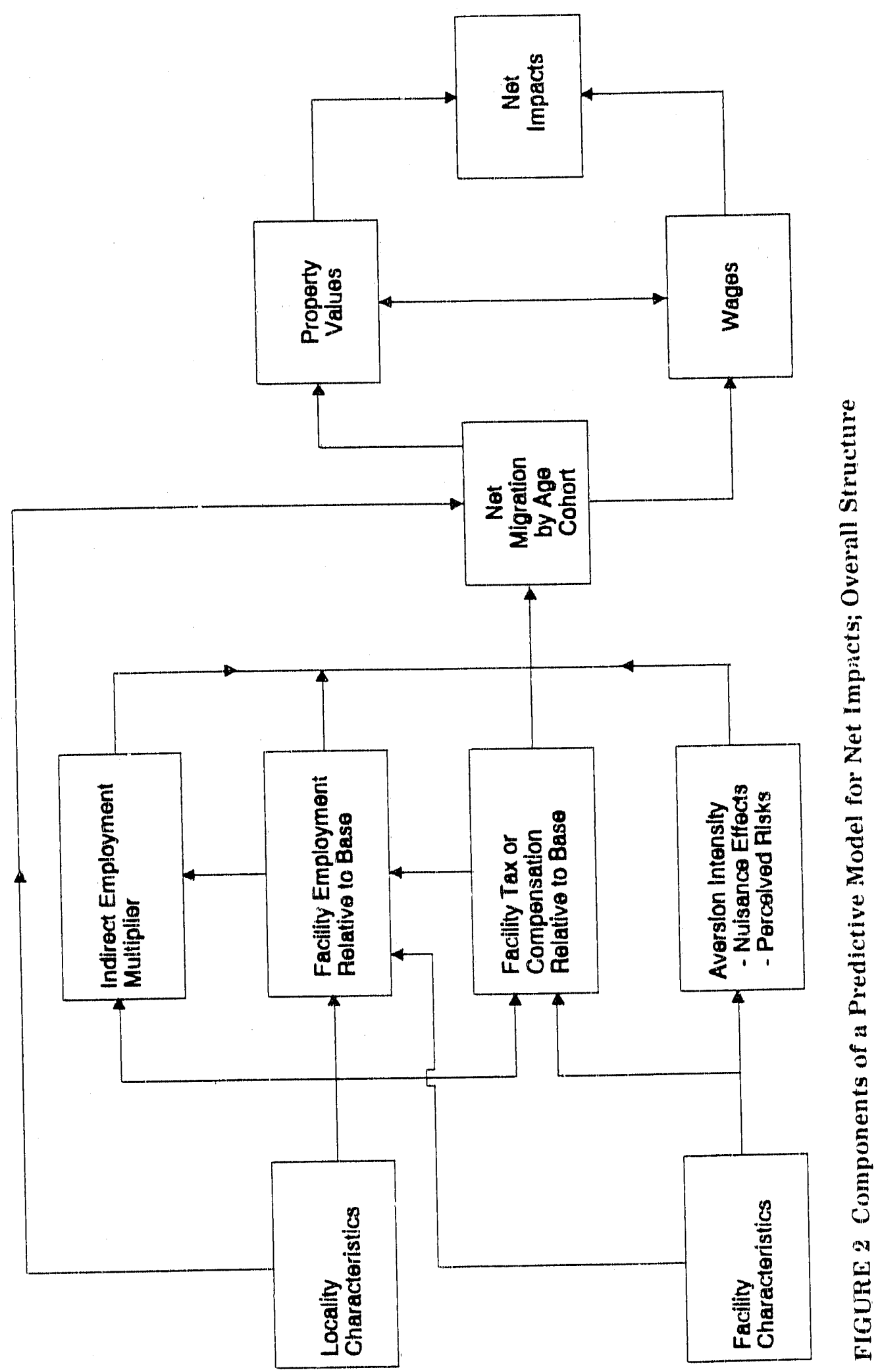


The third key variable is the magnitude of facility tax payments or compensation relative to the tax base. In some cases, a facility may also tend to induce in-migration cor dampen out-migration / by positively affecting the relationship between the taxes paid by local residents and the quantity or quality of government services provided. Better services for given tax rates (or lower tax rates for given service levels) may be brought about by taxes paid by the facility, by payments in lieu of taxes, or by direct compensation to host community organizations. The higher the expected compensation, the less wages must rise and the less property values must fall to attract in-migrants. A recent paper by Stull and Stull (1991) pointed to the effect of local income tax rates on property values, while one by Gyourko and Tracy (1989) examined the tax rate effect in labor markets. The provision of compensation (above-average rates of taxation) to local governments for facility siting complicates estimation of the total facility impact. Total impact is the sum of the compensation, plus the market adjustment in wages and property values.

On the negative side are two key factors that lead to facility aversion and motivate out-migration: (1) the degree to which the facility is perceived to be a nuisance and ( 2 ) the degree to which it is perceived as risky. The role of perceived risks in generating outmigration is indicated both by psychometric studies in which people have stated their desire to avoid facilities considered risky and by hedonic studies that have found depressed property: values around noxious facilities. The nuisance effects of a facility depend on characteristics such as noise, odor, ugliness, traftic congestion, etc. Studies have shown that proximity to airports and freeways reduces property values, probably because of the effects of noise. Some nuisance characteristics such as traflic congestion and odor (McClelland, Schulze, and Hurd 1991) may also serve to remind the public of potential risks, consequently triggering aversion tendencies. If this is generally the case, it will not be possible to separate risk perception from nuisance effects. Their effects will then have to be captured jointly.

Explicit incorporation of facility aversion intensity in the model would require the development of data on the degree to which people want to avoid different types of noxious facilities, including the type of facility for which the impact estimates are desired. Obtaining information on aversion intensity would require a national survey of sufficient size to permit the analysis of difyerences by region and demographic characteristics. While this would involve primary research, the methodology is well developed and results of several prototype surveys are available for analysis.

The relative intensity of aversion to different facility types could then be related to historical patterns of labor and property market adjustments to provide a basis for projecting the likely market adjustments in response to siting a new type of facility. If aversion to the new type of tacility were at the extreme end of the range for existing facilities, the resulting impact projections could fall outside the mange of historical data. This would increase the error range in the impact estimates for the unique facility. This uncertainty could be bounded, however, by estimating alternative functional forms for the relationship between aversion intensity and migration. 


\subsection{LOCALI'TY AND FACILI'TY CHARAC'TERIS'TICS}

The effects on net migration of the key variables discus ied above would be moderated by the constellation of locality and facility characteristics of a specific siting. Figure 2 a shows locality characteristics and their relationships to the key variables.

Effects of a new facility on migration are influenced by characteristics of the locality in which it is situated. The size of the population affects the expansion capacity of the local economy and thus the magnitude of the indirect employment multiplier. Very small population centers may experience greater indirect employment increases than would larger centers. Population size is also generally related to the magnitude of the local tax base and hence moderates the influence of the facility tax or compensation on migration.

According to psychometric studies, the demographic composition of the population affects aversion intensity because of differences in perceptions related to age, sex, education, and child-rearing status. The tendency to migrate also appears to be influenced directly by life-cycle stage. This correspondence may be due, in part, to the differential importance of local amenities to people at different life-cycle stages. 'These effects must be controlled in analyzing noxious facility impacts on migration.

The relative cost of living in an area influences indirect employment growth, since it affects decisions to purchase goods and services locally. An area's industrial structure and unemployment rate also affect the indirect employment multiplier because they provide indications of the expansion capacity of the local economy.

Figure $2 b$ shows the relationships to key variables of the most important facility characteristics (type, size and ownership). Facility type and size intluence aversion intensity as well as facility employment and facility tax or compensation levels. Owner characteristics affect perceived risk through the owner's past management record, the owner's current relationships with local organizations, and the organizational structure within which the owner functions. These characteristics may also affect the level of compensation required to site the facility.

\subsection{NET MARKET IMPACTS}

Migration in and out of areas is constantly occurring as people reach different points in their life cycles, such as graduation from school, career initiation, or retirement to plea ant surroundings. When an area is in equilibrium, property values and wage rates equilibrate these migratory flows so that net migration is zero: the number of in-migrants equals the number of out-migrants. Siting a noxious facility may lead to increased out-migration and decreased in-migration. Within these flows, some age groups may be differentially affected, depending on their perception of facility risks as well as on the importance (to their location decision of employment opportunities, local tiscal characteristics, and amenities. If the effect 


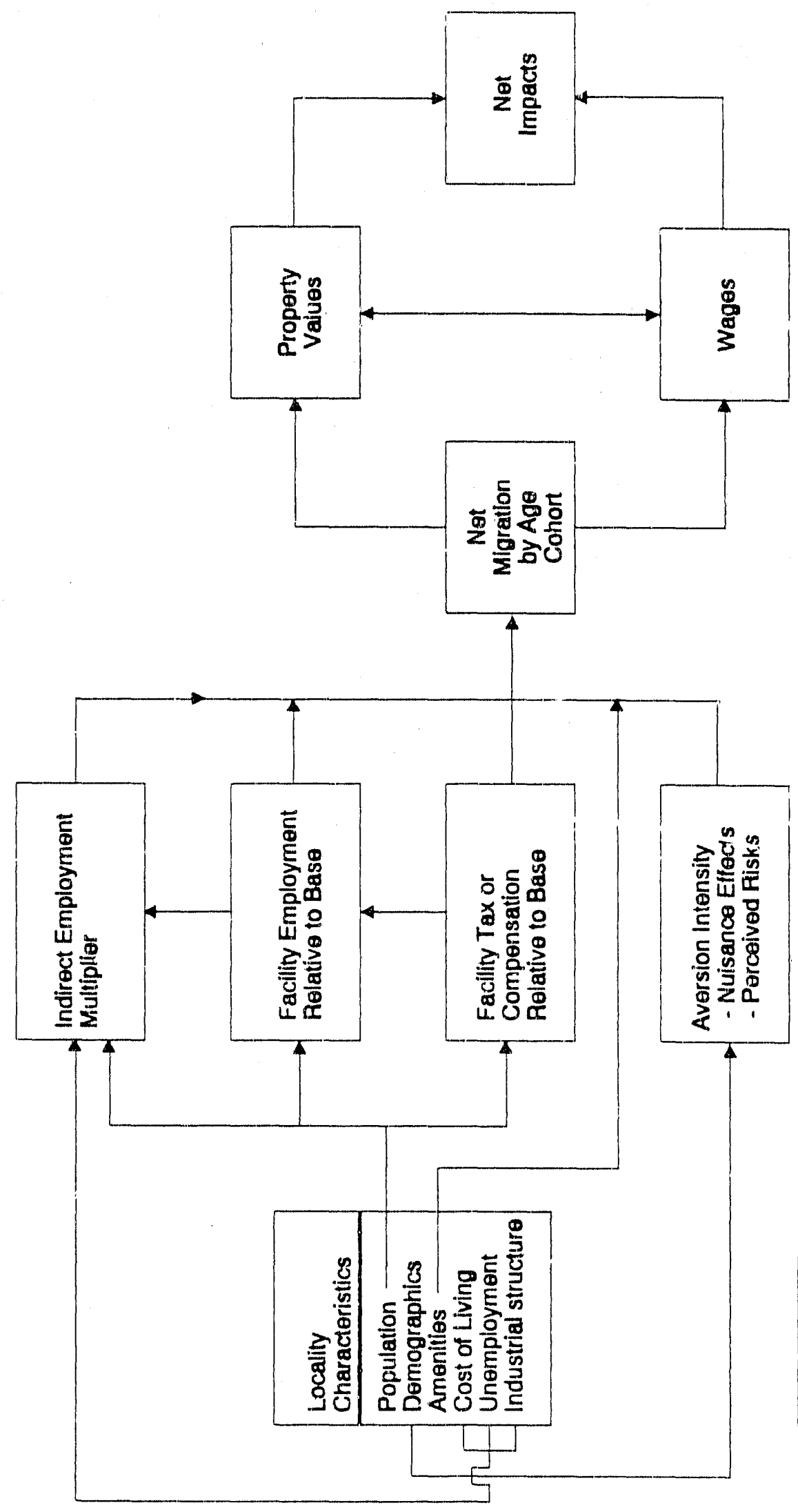

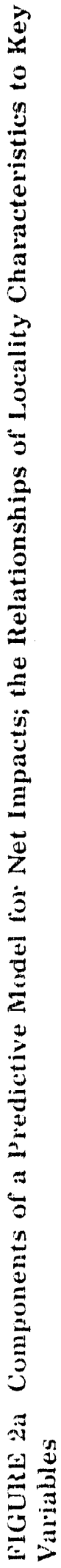




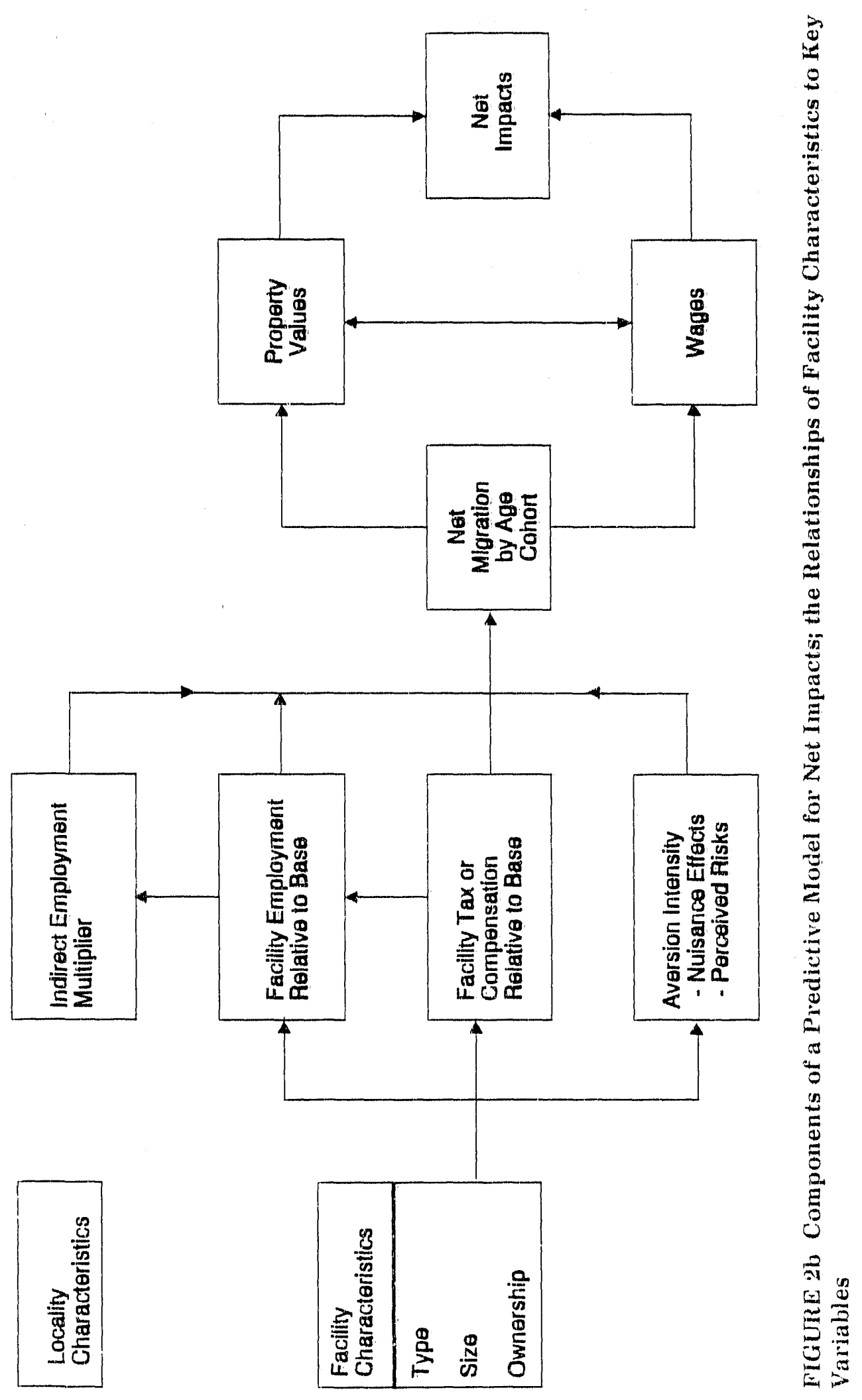


is sufficient to make net migration negative, the demand for housing falls (resulting in decreased property values) and the supply of labor decreases (resulting in increased wages). The sum of these two effects constitutes the net market im pact of the facility on the locality.

Several points need to be made regarding the interpretation of the wage and housing price differentials induced by negative net migration. First, impacts are estimated from historical market data after all movements between regions have taken place. As a result, these estimates are biased because they do not represent the market adjustments needed to induce the original residents to stay. The impacts on the property market are biased upward because individuals perceiving the least risk from the facility are willing to pay the most for nuarby housing and hence locate there. Likewise, the impact on market wages is biased downward because these same individuals also accept the lowest wag: premium for the disamenity. As a new facility is introduced into a region, a series of movements affects wages and property values. Some current residents perceive that the risk is too great and the resulting wage and property value adjustments are too small to entice them to accept the risk. As they move from the area, they are replaced by in-migrants with less risk aversion. Among these, the elderly are more likely to in-migrate in response to lower property values, while workers are more likely to respond to higher wage rates. Overall, the welfare losses from changing the status quo are incurred by the original residents, not by the in-migrants.

Short-run as well as long-run impacts can be estimated. Migration and property value data from the 1980 census would allow estimation of long-run impacts. If used in addition to the 1980 data, the 1990 census data would permit estimation of short-run im pacts as well, which would shed more light on the adjustment process. 


\section{CONCLUSIONS AND RECOMMENDATIONS}

The wage and property value differentials induced by changes in net migration flows can provide a measure of the net economic impact of a noxious facility on a region. These differentials occur as the markets adjust to changes in people's perceptions and expectations regarding the region, including their perceptions of the risks associated with siting a noxious tacility. While short-run changes may be evident in markets for recreation or industry in the region, long-run changes are ultimately reflected in wages and/or property values.

Because of these relationships, local wages and property values can be used to estimate the implicit value of environmental conditions, such as the presence of a noxious facility. A predictive model for the net economic impacts of siting a nuclear waste repository can be developed by hedonic estimation methods and an equilibrium model (with disequilibrium controls) of migration flows. Projection of the likely behavioral response to facility siting requires a psychometric measure of the relative degree of public aversion to a nuclear waste repository and to a range of other noxious facilities.

The changes in property values and wages that individuals would require to stay after a noxious facility is sited in their area, or to move to such an area, can be obtained from either a hedonic/migration model or a contingent valuation survey. Total economic damages that the population will experience from siting a facility can be calculated from these data. The main problem is to determine if the resulting estimates are subject to bias. However. development of both contingent valuation and multiple hedonic models could confirm reliability of the facility impact estimates.

\subsection{MODEL IMPLEMENTATION FEASIBILITY}

The techniques required to project impacts of a nuclear waste repository by using a model of the type depicted in Figure 2 have been implemented in a variety of other contexts. However, they have never been integrated, and their application to noxious facility impact estimation is relatively new. The approach discussed here integrates information from (1) economic base analysis in the form of county-level indirect employment multipliers, (2) psychometric analysis of perceived noxious facility risks for a national sample of respondents, (3) regression analysis of relationships between community and facility characteristics and migration, and (4) hedonic property and labor market analysis relating migration patterns to property values and wages.

County-level data for demographic and economic characteristics are available from the 1980 census; comparable data soon will be available from the 1990 census as well, which will permit evaluation of the short-run adjustment process. An extensive Argonne National Laboratory database of noxious facilities can be used for the model; it will need only the addition of information on facility ownership and size. 
Data for the key variables in the model will need to be obtained or developed. Possible data sources for the facility employment and tax-related variables are as follows:

- Facility employment. For noxious facilities that are part of the manufacturing sector, such as refineries, average employment per establishment can be estimated from the county-level data supplied in the Survey of Manufactures published by the U.S. Bureau of the Census; or employment size class information for specific establishments can be obtained from the National Directory of Manufacturers published by American Business Directories. Data on employment by utilities and government-operated facilities would have to be obtained from other sources.

- Indirect employment multiplier. County-level multipliers are available from the Bureau of Economic Analysis Regional Industrial Multiplier System (RIMS) program. These would need to be evaluated and moditied, if necessary.

- Facility tax/compensation and base tax revenues. Financial statistics for local governmental entities are collected by the U.S. Bureau of the Census in its Census of Governments and reported on in publications such as the Annual Survey of Government Finance Statistics. IThe annual survey is based on a sample that provides only partial coverage of some states.) Data sources would need to be compared and in tegrated if possible.

Data on the intensity of facility aversion can be developed through the use of psychometric survey methods. This task will require primary research to develop and test a survey instrument, develop a sampling design that will permit subgroup analyses, and administer the survey and record data. It will also require substantial administrative as well as research effort, but it could be designed to provide information to meet multiple objectives.

Once the data for the key variables have been assembled, estimation of their relationship to migration flows and of those flows to property values and wages are the remaining tasks. This effort would involve application of hedonic estimation techniques similar to those previously employed by the authors and others in measuring impacts of a variety of environmental effects.

\subsection{POTENTIAL AND LIMITATIONS OF THIS APPROACH}

The research approach described above allows development of ex ante estimates for perception-based economic impacts. However, it also involves analytical methods that, although they have been individually tested in a variety of contexts, have never been integrated in the manner described here. Problems may arise from the complexity of the 
estimation required and from unexpected sources. Resulting impact estimates would not be for risk perception alone but for nuisance effects as well.

Estimating impacts for a nonexistent facility type requires collecting survey data about the interviewees' projections of their aversion to its hypothetical existence. Although the accuracy of their responses will vary depending on the degree to which they can envision the future facility, these surveys provide the best obtainable measure of actual perceptions. The accuracy of the responses should increase as aspects of the facility become defined more clearly.

Using psychometric estimates of aversion intensity for a nonexistent facility type to project economic im pacts may lead to results outside the range of historical experience. Thus, the error associated with the estimated impacts may be larger than that for existing facility types. Given the uncertainties, it would be best to bound the range of possible impacts by examining various forms of relationships of impact levels with public aversion to the facility. As an additional confirmatory measure, it would be advisable to employ multiple estimation methods in the hedonic analysis and to include a contingent valuation survey while the psychometric data are being collected. 


\section{REFERENCES}

Bajgier, S.M., and H. Moskowitz, 1978, Public Risk Assessment and Evaluation of Drinking Water Quality, J. Interdisciplinary Modeling and Simulation, 1(2):143-178.

Baker, M.D., 1986, Property Values and Potentially Hazardous Production Facilities: A Case Study of the Kancuwha Valley, West Virginia, Ph.D. Dissertation, The Florida State University, Tallahassee.

Biddle, J., and G. Zarkin, 1988, Worker Preferences and Market Compensation for Job Risk, The Review of Economics and Statistics, 70(Nov.):660-667.

Blornquist, G., 1974, The Effect of Electric Utility Pouer Plant Location on Area Property Value, Land Economics, 50(Feb.):97-100.

Brookshire, D.S., and T.D. Crocker, 1981, The Advantages of Contingent Valuation Methods for Benefit-Cost Analysis, Public Choice, 36(2):235-252.

Brown, C., 1980, Equalizing Differences in the Labor Market, The Quarterly J. Economics, pp. 113-134, Feb.

Burnell, J.D., 1985, Industrial Land Use, Externalities, and Residential Location, Urban Studies, 22:399-408.

Cronin, F.J., 1982, Valuing Nonmarket Goods through Contingent Markets, prepared for the U.S. Environmental Protection Agency, Pacific Northwest Laboratory Report PNL-4255.

Doherty, L.E., 1964, Tuna's Time of Trouble, Food Business, pp. 28-34, Jan.

Freeman, A.MI., III, 1979, Hedonic Prices, Property Valiees, and Measuring Environmental Benefits: A Survey of the Issues, Scandinavian J. Economics, 81(2):154-173.

Gamble, H.B., and R.H. Downing, 1982, Effects of Nuclear Power Plants on Residential Property Values, J. Regional Science, 22(4):45'7-478.

Golant, S., and I. Burton, 1969, Avoidance-Response to the Risk Environment, Natural Hazard Research, Working Paper No. 6, University of Toronto, Torunto.

Grether, D.M., and P. Mieszkowski, 1980, The Effects of Nonresidential Land Uses on the Prices of Adjacent Housing: Some Estimates of Proximity Effects, J. Urban Economics, 8:1-15.

Griswold, D., ed., 1972, Combating Alleged Danger of a Product, Pubic Relations News, $28(21)$.

Gyourko, J., and J. Tracy, 1989, The Importance of Local Fiscal Conditions in Analyzing Local Labor Markets, J. Political Economy, 97(5):1208-1231. 
Harrison, D., Jr., and J.H. Stock, 1984, Hedonic Housing Values, Local Public Goods, ard the? Bervefits of Hazardous Waste? Clearup, Energy and Environmental Policy Center, Harvard University, Cambridge, Mass.

Herzog, H., and A. Schlottman, 1990, Valuing Risk in the Wortiplace: Market Price, Willingness to Pay, and the Optimal Provision of Safety, The Review of Economics and Statistics, pp. $465-470$.

Hoehn, J.P., M.C. Berger, and G.C. Blomquist, 198'7, A Hedonic Model of Interregional Wages Rents, and Amenity Values, .J. Regional Science, 27(4):605-620.

Kahneman, D., P. Slovic, and A. Tversky, 1982, "Judgement under Uncertainty: Heturistics and Biases, Cambridge University Press, Cambridge, England.

Kasperson, R.E., et al., 1988, The Social Amplification of Risk: A Conceptual Frameturerk. Risk Analysis, 8(2):177-187.

Kiecolt, K.J., and J.M. Nigg, 1982, Mobility and Perceptions of a Hazardous Encuironment, Environment and Behavior, 14(2):131-154.

Knapp. T.A., and P.E. Craves, 1989, On the Role of Amenities in Models of Migration cmd Regionral Development, .J. Regrional Science, 29(1):71-87.

Kunceuther, H., W.H. Desvousges, and P. Slovic, 1988, Nevada's Predicamert, Envitonment. $30(8): 17-20,30-33$.

Lindell, M.K., and T.O. Earle, 1983, How Close Is Close Enough: Public Perceptions of the Risks of Industrial Facilitie's, Risk Analysis, 3(4):24.5-253.

Maderthaner, R., et al., 1976, Perception of Technological Risks: The Effect of C'onfrontrution, International Institute for Applied Systems Analysis Research Memorandum RM-76-53, Laxenburg, Austria, June.

Mathur, V.K., and S.H. Stein, 1991, A Dynarnic Interregional Theory of Migration and Population Growth, Land Economics, 67(3):292-98.

McClelland, G.H., W.D. Schulze, and B. Hurd, 1990, The Effect of Risk Beliefs on Property Values: A Case Study of a Hazardous Waste Site, Risk Analysis, 10(4):485-497.

Michaels, G., and K. Smith, 1990, Market Segmentation and Valuing Amenities with Hedonic Models: The Case of Hazardous Waste Sites, J. Urban Economics, 23:223-242.

Mountain West Research, 1989, Yucca Mountain Socioeconomic Project Preliminary Findings: 1989 Nevada State Telephore Surtey, State of Nevada, Nuclear. Waste Project. Office Report NWPO-SE-025-89, June. 
Nelson, J.P., 1981, Thre'e Mile' Island and Re'sidential Property Values: Empirical Analysis and Policy Implications, Land Econonics, 57(3):3633-372.

Nieves, L.A., R.C. Hemphill, and D.E. Clark, 1991, The Economir Impotes of Noxious Facilities on Wages and Property Values: An Exploratory Analysis, Argonne National Laboratory Report ANL/EAIS/TM-67.

Randall, A., J.P. Hoehn, and D.S. Brookshire, 1983, Contingent Valuction Surteys for Evaluating Environmental Assets, Natural Resources J., 2:3131:635-648.

Real Estate Counseling Group of Connecticut, Inc., and Financial Consulting Croup of Ohio, 1987, Patterns of Real Estate Market Behauior around the Fe'd Materials Production Center Fernald, Ohio, Vol. I.

Real Estate Counseling Group of Connecticut, Inc., and Financial Consulting Group of Ohio, 1989, Patterns of Real Estate Market Behavior around the Feed Materials Production Center Fernald, Ohio, Vol. II.

Roback, J., 1982, Wages, Rents, and the Quality of Life, J. Political Economy, 90(6):1257.-1273.

Schachter, J., and P.G. Althaus, 1989, An Equilibritum Model of Gross Migration, .J. Regional Science, $29(2): 143-159$.

Schmalensee, R., et al., 1975, Mectsuring External Effects of Solid Waste Mancugernernt, prepared for the U.S. Environmental Protection Agency, Otfice of Research and Development, March.

Seller, C., J.R. Stoll, and J.P. Chavas, 1985, Validation of Empirical Mecasures of Welfure. Change: A Comparison of Nonmarket Techniques, Land Economics, 61(2):L56-175.

Smith, V.K., and W.H. Desvousges, 1986, Asymmetries in the Valuation of Rish und the Siting of Hazardous Waste Disposal Facilities, American Economic Review, Papers and Proceedings, $76(2): 291-294$.

Smith, V.K., and W.H. Desvousges, 1987, An Empirical Anculysis of the' Econornic Valut of Risk Changes, J. Political Economy, 95(1):89-113.

Stull, W.J., and J.C. Stull, 1991, Capitalization of Local Income Taxes, J. Urban Economics, 29(2):182-190.

Swartz, D.G., and I.E. Strand, Jr., 1981, Avoidance Costs Associated with Imperfect Information: The Case of Fepone, Land Economics, 57(2):139-150.

Taylor, J.W., 1974, The Role of Risk in Consumer Behauior, s. Marketing, 38:54-60. 
Thaler, R., and S. Rosen, 1976, The Value of Saving a Life: Evidence from the Labor Market, in N.E. Terleckyj, ed., Household Production and Consumption, Columbia University Press, New York. 

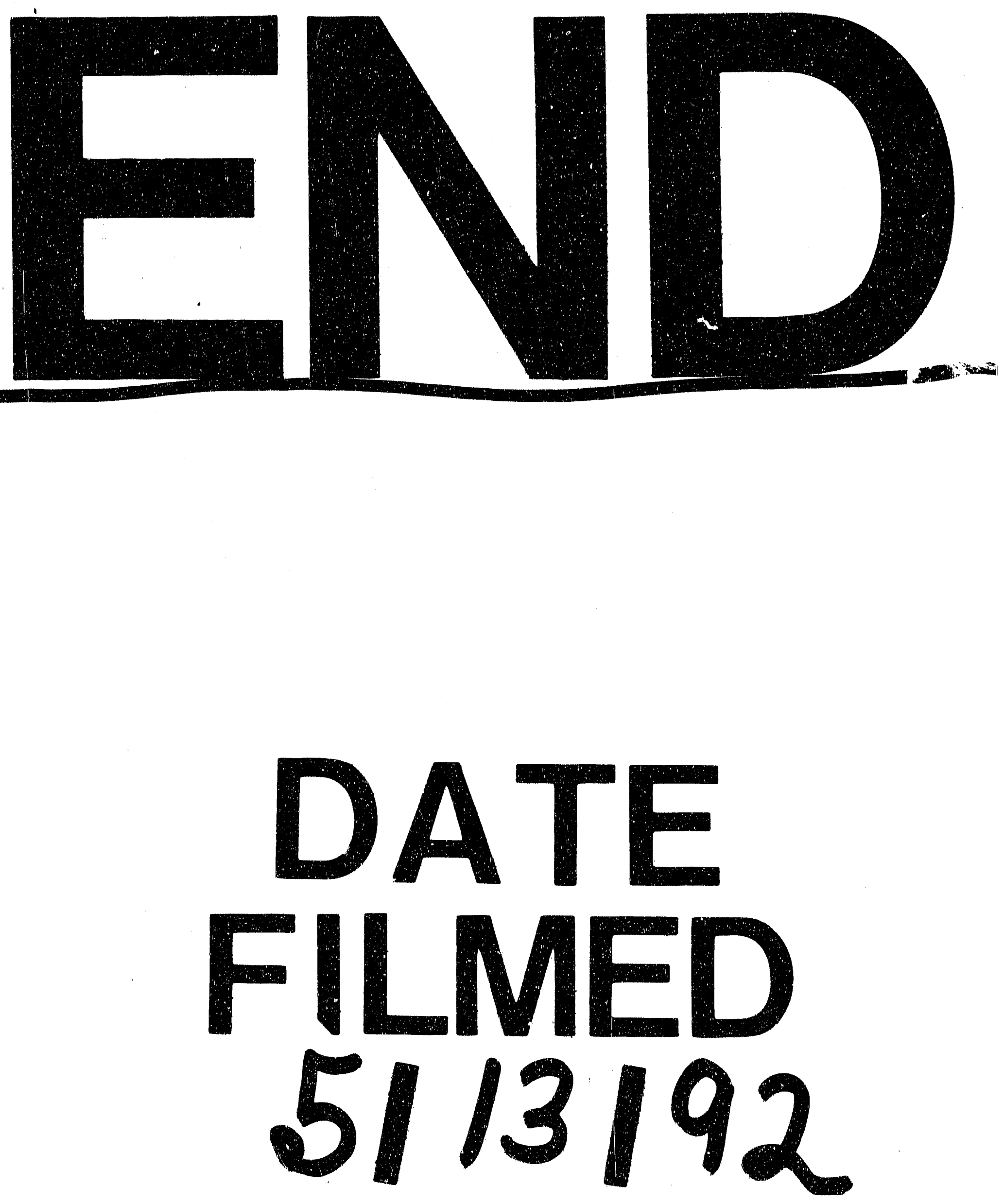


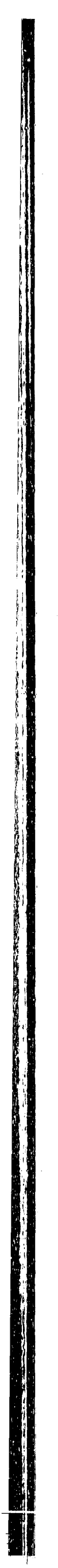

